\title{
Deafferentation Elicits Increased Dopamine-Sensitive Adenylate Cyclase and Receptor Binding in the Olfactory Tubercle
}

\author{
Russell B. Lingham* and Zehava Gottesfeld $\dagger$ \\ Departments of *Pharmacology and +Neurobiology and Anatomy, University of Texas Medical School at \\ Houston, Houston, Texas 77025
}

\begin{abstract}
Removal of a major non-catecholaminergic output from the olfactory bulb elicits sprouting of dopaminergic axons in the olfactory tubercle. The functional consequences of this increased dopaminergic innervation are presently not known. This study examined the question of whether lesion-induced sprouting of dopaminergic axons is associated with changes in dopaminesensitive adenylate cyclase and dopamine receptor density in the partially denervated olfactory tubercle. The results indicate that (1) dopamine- and NaF-stimulated adenylate cyclase activity increased as early as $7 \mathrm{~d}$, while forskolin-sensitive activity increased at $3 \mathrm{~d}$ and persisted up to $20 \mathrm{~d}$ after lesioning; (2) higher levels of GTP- and NaF-stimulated enzyme activity were found in detergent extracts of olfactory tubercle membranes from 20 d lesioned rats; (3) higher levels of ${ }^{3} \mathrm{H}$-forskolin binding were found in membranes from 14 and $20 \mathrm{~d}$ lesioned rats; and (4) there was an increase in dopamine receptor density, but not affinity, in olfactory tubercle membranes from lesioned rats. The data indicate that lesion-induced dopaminergic sprouting in the olfactory tubercle is temporally coordinated with the increased formation of dopamine receptors, both $D_{1}$ and $D_{2}$, the stimulatory guanine nucleotide regulatory protein $\left(\mathrm{N}_{\mathrm{s}}\right)$ and the catalytic subunit $(\mathrm{C})$ of adenylate cyclase in the postsynaptic membranc.
\end{abstract}

There is increasing evidence that partial deafferentation can induce sprouting of nearby intact axon terminals and, in some cases, they have been shown to establish de novo synaptic contacts with the dencrvated cell (Cotman, 1978, for review). Formation of new synaptic junctions with the target neuron is associated with plastic changes involving presynaptic axonal growth, as well as postsynaptic alterations. To date, an increasing number of studies have focused on the cellular mechanisms of axonal growth and regeneration, while few studies are available on the response of the postsynaptic membrane to lesioninduced sprouting. This specialized membrane structure contains specific neurotransmitter receptors, ionophores, regulatory enzymes, and other molecules that may play a role in synaptic transfer of information. Knowledge concerning these components will provide a better understanding of synaptic plasticity in response to partial deafferentation.

Destruction of a major non-catecholaminergic output from the olfactory bulb elicits sprouting of dopaminergic axon ter-

\footnotetext{
Received July 29, 1985; revised Jan. 27, 1986; accepted Feb. 17, 1986.

We thank Vien Holcombe and Christopher Garcia for expert technical assistance and Heidi Porter for typing the manuscript. This work was supported in part by NIH Grants GM 27378 (awarded to G. Alan Robison), NS 19325 and AA 06158 (awarded to Z.G.), and National Science Foundation BNS-8401818 (awarded to Z.G.). R.B.L. thanks Dr. Robison for providing financial support and laboratory facilities during the course of this study.

Correspondence should be addressed to Dr. Lingham, Department of Pharmacology, Box 20708, University of Texas Medical School at Houston, Houston, TX 77025.

Copyright (c) 1986 Society for Neuroscience $0270-6474 / 86 / 082208-07 \$ 02.00 / 0$
}

minals in the olfactory tubercle (Gilad and Reis, 1979; Moore, 1974). This growth of dopaminergic axons was identified by (1) increased activity and amount of tyrosine hydroxylase, (2) increased high-affinity uptake of ${ }^{3} \mathrm{H}$-dopamine into synaptosomes from olfactory tubercles, and (3) increased immunoreactive staining of tyrosine hydroxylase-containing axon terminals (Gilad and Reis, 1979). The mode of interaction with specific postsynaptic components and the functional consequences of this increased dopaminergic innervation are not known. The present study was initiated to address the question of whether lesioninduced sprouting of dopaminergic axons in the olfactory tubercle is correlated with altered dopamine-sensitive adcnylatc cyclase activity and dopamine receptor density in the postsynaptic site. The adenylate cyclase system is an integral component of the postsynaptic membrane (Drummond, 1983), and in the olfactory tubercle, it is associated with postsynaptic receptors for dopamine (Church ct al., 1982; Krieger, 1980) that is released by axons emanating from perikarya in the midbrain ventral tegmentum (Ungerstedt, 1968). This work demonstrates that lesion-induced sprouting of dopaminergic axons in the olfactory tubercle is associated with (1) increased dopamine-sensitive adcnylate cyclase activity, (2) increased density of $D_{1}$ and $D_{2}$ dopamine receptors, (3) increased levels and/or activity of the stimulatory GTP-binding protein $\left(\mathrm{N}_{\mathrm{s}}\right)$ that couples $\mathrm{D}_{1}$ dopamine receptors to the catalytic subunit $(\mathrm{C})$ of adenylate cyclase, and (4) increased levels of $C$ in the postsynaptic membrane.

\section{Materials and Methods}

\section{Materials}

$\left(\alpha-{ }^{32} \mathrm{P}\right)$-ATP $(1000 \mathrm{Ci} / \mathrm{mmol})$ was purchased from ICN Radiochemicals (lrvine, Ca); ${ }^{3} \mathrm{H}$-cis-flupenthixol and ${ }^{3} \mathrm{H}$-spiperone were purchased from New England Nuclear (Boston, MA). Tris maleate, EGTA, NaF, ATP, pyruvate kinase, phospho(enol) pyruvate, and dopamine were purchased from Sigma Chemical Company (St. Louis, MO). GTP and 5'guanylylimidodiphosphate $(\mathrm{Gpp}(\mathrm{NH}) \mathrm{p})$ were obtained from Boehringer-Mannheim Biochemicals (Mannheim, F.R.G.). All other reagents and solvents were of analytical grade.

\section{Animals and surgical procedures}

Male Sprague-Dawley rats, 200-250 gm (Timco; Houston, TX), were anesthetized with Chloropent solution, $3 \mathrm{ml} / \mathrm{kg}$ (Fort Dodge Laboratories, IA). The olfactory bulbs were exposed and removed bilaterally by aspiration, while sham-operated controls underwent similar treatments, except that the olfactory bulbs remained intact. The animals were allowed to recover for different time periods after operation and were then killed by decapitation. The brain was placed, dorsal side down, on a cold plate $\left(0-4^{\circ} \mathrm{C}\right)$ under the stereobinocular. Both olfactory tubercles, which are easily discerned on the ventral side, were dissected along its borders and removed from adhering neighboring forebrain regions. The slice of superficial layer of tubercle tissue, less than $2 \mathrm{~mm}$ thick, was completely devoid of adjacent tissue and of the underlying white matter. The consistency of this surgical procedure was verified in a separate set of experiments by weighing the tissues. The weight of 
each tubercle was found to lie within a narrow range $(11 \pm 0.6 \mathrm{mg}, n=$ 12) for both control and lesioned groups. The olfactory tubercles were removed, quick-frozen on dry ice, and stored at $-70^{\circ} \mathrm{C}$ until use.

\section{Membrane preparation}

On the day of assay, frozen olfactory tubercles were rapidly thawed and homogenized with $40 \mathrm{vol}(\mathrm{wt} / \mathrm{vol})$ of an ice-cold solution containing 2 mM Tris maleate, $\mathrm{pH} 7.5,2 \mathrm{~mm}$ EGTA, 2 mM $\mathrm{MgCl}_{2}, 320$ mM sucrose, and $1 \mathrm{~mm}$ phenylmethylsulfonyl fluoride. The homogenate was centrifuged at $48,000 \times g$ in a JA 21 rotor (Beckman) for $20 \mathrm{~min}$ at $4^{\circ} \mathrm{C}$. The supernatant was discarded, and the pellet was resuspended in a volume, equal to the original homogenizing volume, of icc-cold $2 \mathrm{~mm}$ Tris maleate, $\mathrm{pH} 7.5,2 \mathrm{~mm}$ EGTA, and $2 \mathrm{~mm} \mathrm{MgCl}_{2}$ (buffer A). The suspension was centrifuged as described above and the pellet was washed once more with buffer $A$. The final pellet was resuspended in buffer A (3-4 mg/ $\mathrm{ml})$ and was either used immediately or divided into small $(100 \mu \mathrm{l})$ aliquots, quick-frozen with dry ice and acetone, and stored at $-70^{\circ} \mathrm{C}$ until use.

\section{Adenylate cyclase assay}

Adenylate cyclase activity was assayed as described by Salomon (1979). Briefly, membranes were incubated in a final volume of $100 \mu \mathrm{l}$ of a solution containing $80 \mathrm{~mm}$ Tris maleate, $\mathrm{pH} 7.5,0.6$ Imм EGTA, $2 \mathrm{~mm}$ ethylenediamine-tetraacetic acid (EDTA), $0.15 \mathrm{~mm}$ dithiothreitol (DTT), $8 \mathrm{mM} \mathrm{MgCl}_{2}, 0.5 \mathrm{~mm}$ isobutylmethyl xanthine, $0.16 \mathrm{mg} / \mathrm{ml} \mathrm{BSA}, 4.8$ $\mathrm{mM}$ potassium phospho(enol) pyruvate, $16 \mu \mathrm{g} / \mathrm{ml}$ pyruvate kinase, and $0.5 \mathrm{~mm}\left(\alpha-{ }^{32} \mathrm{P}\right)$-ATP $\left(1-2 \times 10^{6} \mathrm{cpm} / \mathrm{assay}\right)$.

Activators, when used in the assay, were routinely used at the following concentrations: GTP, $100 \mu \mathrm{M}$; Gpp(NH)p, $50 \mu \mathrm{M}$; dopamine, $100 \mu \mathrm{M} ; \mathrm{NaF} / \mathrm{AlCl}_{3}, 10 \mathrm{~mm} / 20 \mu \mathrm{M}$; and forskolin, 10-100 $\mu \mathrm{M}$. Dopamine was dissolved in $23 \mu \mathrm{M}$ ascorbate, while forskolin was dissolved in $95 \%$ ethanol. The final ethanol concentration in the assay was $0.05 \%$, which had no effect on adenylate cyclase activity.

Membranes were usually preincubated for $15 \mathrm{~min}$ on ice in the presence of activators. The assay was started by the addition of the $\left(\alpha-{ }^{32} \mathrm{P}\right)$ ATP and incubation at $30^{\circ} \mathrm{C}$ for $20 \mathrm{~min}$. The reaction was stopped with $800 \mu \mathrm{l}$ of a solution containing $0.25 \%$ SDS, $5 \mathrm{~mm} \mathrm{ATP}$, and $0.175 \mathrm{~mm}$ cAMP. One hundred microliters of a solution containing $1 \times 10^{4} \mathrm{cpm}$ ${ }^{3} \mathrm{H}-\mathrm{cAMP}$, and $0.1 \mathrm{~mm}$ unlabeled cAMP were added to each assay tube to monitor the recovery of $\left(\alpha^{-32} \mathrm{P}\right)$-cAMP. Radioactive cAMP was separated from $\left(\alpha{ }^{32} \mathrm{P}\right)$-ATP by sequential chromatography over Dowex Ag $50 \mathrm{~W}-\mathrm{X} 4$ and alumina oxide columns. The recovery of $\left(\alpha-{ }^{32} \mathrm{P}\right)$-cAMP was usually greater than $60 \%$.

\section{Solubilization of the stimulatory guanine nucleotide regulatory protein, $\mathrm{N}_{\mathrm{s}}$}

Olfactory tubercle membranes from control or lesioned animals were prepared as described above. Membranes were extracted with $20 \mathrm{~mm}$ Tris $\mathrm{HCl}, \mathrm{pH} 8.0,1 \mathrm{~mm}$ EDTA, $1 \mathrm{~mm}$ DTT, and $1 \%$ cholate. After it was stirred at $4^{\circ} \mathrm{C}$ for $60 \mathrm{~min}$, the suspension was centrifuged at 40,000 $\mathrm{rpm}$ in a Ty 40 rotor (Beckman) for $60 \mathrm{~min}$. The soluble extract from control or lesioned membranes was diluted at least 50 -fold with $20 \mathrm{~mm}$ Tris $\mathrm{HCl}$, pH 8.0, $1 \mathrm{~mm}$ EDTA, $1 \mathrm{~mm}$ DTT, $100 \mathrm{~mm} \mathrm{NaCl}$, and $0.1 \%$ Lubrol prior to being reconstituted and assayed with $\$ 49$ lymphoma cyc $^{-}$membranes as described by Sternweis et al. (1981).

\section{${ }^{3} H$-spiperone binding assay}

Membranes ( $50 \mu \mathrm{g}$ protein/tube) were incubated with varying amounts of ${ }^{3} \mathrm{H}$-spiperone for $30 \mathrm{~min}$ at $25^{\circ} \mathrm{C}$ in a buffer containing $2 \mathrm{~mm}$ Tris maleate, pH 7.5, $100 \mathrm{~mm} \mathrm{NaCl}, 2 \mathrm{~mm} \mathrm{CaCl}_{2}, 5 \mathrm{~mm} \mathrm{KCl}, 2$ mм EGTA, $1 \mathrm{mM} \mathrm{MgCl}_{2}$, and $1 \mu \mathrm{M}$ mianserin ( $1 \mathrm{ml}$, final volume). (+)-Butaclamol ( $1 \mu \mathrm{M}$ ) was used to measure nonspecific binding, while total binding was measured in the presence of $0.002 \%$ ascorbic acid. The assay was stopped by filtration over glass fiber filter disks (Whatman GF/B) soaked in 50 mM Tris maleate, $\mathrm{pH} 7.5$, containing $0.02 \% \mathrm{BSA}$. Filters were washed rapidly 3 times ( $5 \mathrm{ml}$ each) with the same buffer. The filters were dried, placed in scintillation vials with $7 \mathrm{ml}$ of scintillation cocktail (3a70B, Research Products International), and rapidly shaken for $2 \mathrm{hr}$. The vials were counted at $50 \%$ efficiency, and specific binding was calculated as the difference between total and nonspecific binding.

\section{${ }^{3} H$-cis-flupenthixol binding assay}

${ }^{3} \mathrm{H}$-cis-flupenthixol binding to olfactory tubercle membranes from control or lesioned animals was assayed essentially as described by Leff et

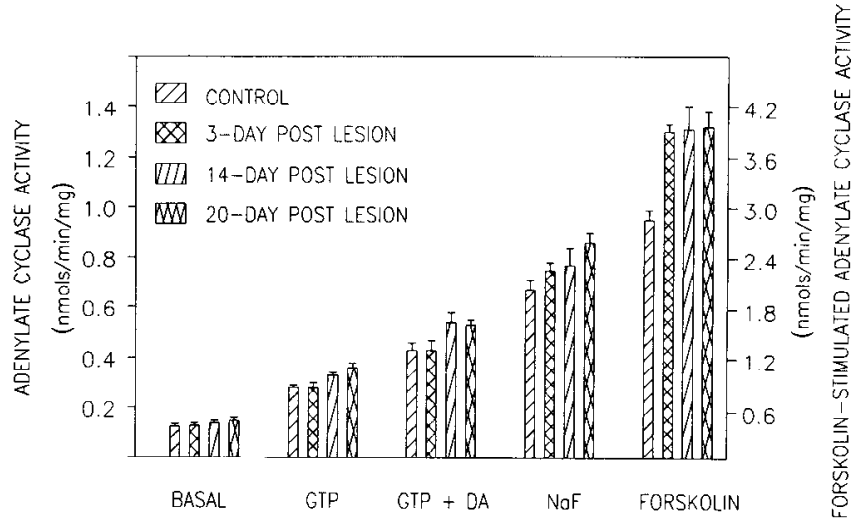

Figure 1. Adenylate cyclase activity in membranes from control or lesioned rats. Animals were either sham-operated or lesioned, allowed to recover for various periods of time, and killed by decapitation; olfactory tubercles were removed, quick-frozen on dry ice, and stored at $-70^{\circ} \mathrm{C}$. Membranes were prepared by homogenization and differential centrifugation as described in Materials and Methods. Adenylate cyclase activity-in the presence of $100 \mu \mathrm{M}$ GTP, $100 \mu \mathrm{M}$ dopamine plus 100 $\mu \mathrm{M}$ GTP, $10 \mathrm{mM} \mathrm{NaF}$ plus $20 \mu \mathrm{M} \mathrm{AlCl}_{3}$, and $10 \mu \mathrm{M}$ forskolin-was assayed as described in the text.

al. (1985). Membranes (100-150 $\mu \mathrm{g}$ protein/tube) were incubated in 2 $\mathrm{ml}$ (final volume) of a solution containing $40 \mathrm{~mm} 3-[\mathrm{N}$-morpholino]-2hydroxypropanesulfonic acid, $\mathrm{pH} 7.5,4 \mathrm{mM} \mathrm{MnSO}_{4}, 1 \mathrm{~mm}$ EDTA, $0.1 \%$ ascorbic acid, and $1 \mathrm{nM}^{3} \mathrm{H}$-cis-flupenthixol. Total binding was measured in the presence of $30 \mathrm{~nm}$ spiperone while nonspecific binding was measured in the presence of $1 \mu \mathrm{M}(+)$-butaclamol plus $30 \mathrm{nM}$ spiperone. Assay tubes were routinely incubated at $30^{\circ} \mathrm{C}$ for $60-90 \mathrm{~min}$. The reaction was terminated by filtration over $\mathrm{GF} / \mathrm{C}$ filters that had been soaked in $50 \mathrm{~mm}$ Tris maleate, $\mathrm{pH} \mathrm{7.5}$, and $0.1 \%$ BSA. Filters were washed 5 times $(5 \mathrm{ml}$ each) with the same buffer. Radioactivity trapped on the filters was counted by liquid scintillation spectroscopy (50\% efficiency).

\section{${ }^{3} H$-forskolin binding assay}

${ }^{3} \mathrm{H}$-forskolin binding to olfactory tubercle membranes from control or lesioned animals was assayed according to Nelson and Seamon (1985). Membranes (200-400 $\mu \mathrm{g}$ protein/tube) were incubated in $0.4 \mathrm{ml}$ (final volume) of a solution containing $50 \mathrm{~mm}$ Tris $\mathrm{HCl}, \mathrm{pH} 7.5,10 \mathrm{~mm}$ $\mathrm{MgCl}_{2}$, and $10 \mathrm{nM}^{3} \mathrm{H}$-forskolin. Total binding was measured in the absence of forskolin, while nonspecific binding was measured in the presence of $20 \mu \mathrm{M}$ forskolin. Assay tubes were incubated at $25^{\circ} \mathrm{C}$ for 60 $\min$. The reaction was terminated by filtration over $\mathrm{GF} / \mathrm{C}$ filters and washed 5 times with $50 \mathrm{~mm}$ Tris $\mathrm{HCl}, \mathrm{pH} 7.5$, containing $0.1 \%$ BSA. Filters were presoaked in the same medium to lower nonspecific binding of ${ }^{3} \mathrm{H}$-forskolin. Radioactivity trapped on the filters was counted by liquid scintillation spectroscopy ( $50 \%$ efficiency).

\section{Protein assay}

Protein concentrations were routinely measured as described by Bradford (1976) or Schaffner and Weissman (1973), using BSA as standards.

\section{Results}

\section{Effects of various activators on adenylate cyclase activity in olfactory tubercle membranes of control and lesioned rats}

Adenylate cyclase activity in the presence of various activators was assayed; the results are presented in Figure 1. The basal activity of adenylate cyclase (that is, in the absence of GTP or dopamine) for the 3 time periods $(3,14$, and $20 \mathrm{~d}$ after operation) was the same as control. Since there was no difference between the 3 and $14 \mathrm{~d}$ sham-operated rats, the data obtained from these animals have been pooled. Dopamine and GTP increase enzyme activity, especially 14 and $20 \mathrm{~d}$ after lesioning.

NAF increases adenylate cyclase activity by promoting the 
Figure 2. Dopamine-sensitive adenylatc cyclase activity in control or lesioned membranes. Olfactory tubercle membranes from control and lesioned animals were prepared as described. Adenylate cyclase activity, in the presence of increasing concentrations of dopamine, was assayed as described in Materials and Methods.

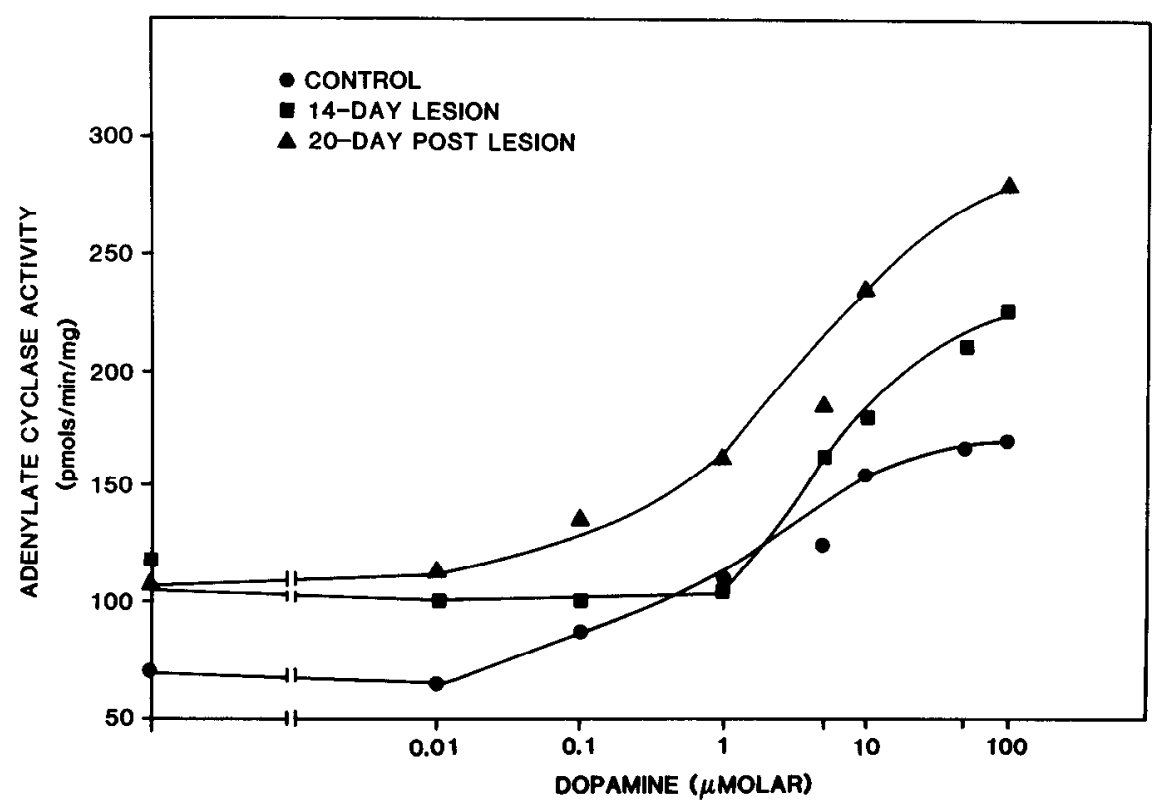

activation of $\mathrm{N}_{\mathrm{s}}$ (Ross and Gilman, 1980; Ross et al., 1978), which then interacts with C (Smigel et al., 1984) to catalyze the conversion of ATP to cAMP. NaF in the presence of $\mathrm{AlCl}_{3}$ (Sternweis and Gilman, 1982) activates the enzyme about 6-fold above basal levels. The NaF-stimulated activity is higher 14 and $20 \mathrm{~d}$ after lesioning compared to control or $3 \mathrm{~d}$ lesioned membranes.

Forskolin is believed to activate $\mathrm{C}$ directly (Seamon and Daly, 1981), and this stimulation can be potentiated by guanine nucleotides and $\mathrm{N}_{\mathrm{s}}$ (Green and Clark, 1982). Forskolin increased $C$ activity of membranes from control and postoperative rats by close to 20 - and 26 -fold, respectively, above basal levels. The forskolin activation of $\mathrm{C}$ was similar in all 3 lesioned groups, but this was markedly higher than control membranes.

An increase in the affinity, as well as in density of receptors for dopamine, could account for the increase in dopamine-sensitive enzyme activity in membranes from lesioned animals. To examine the question of whether lesioning affected the affinity of receptors for dopamine in terms of functionally coupling $\mathrm{N}_{\mathrm{s}}$ to $\mathrm{C}$, we performed the cxpcriment presented in Figure 2. There was no difference in enzyme activity between control and $3 \mathrm{~d}$

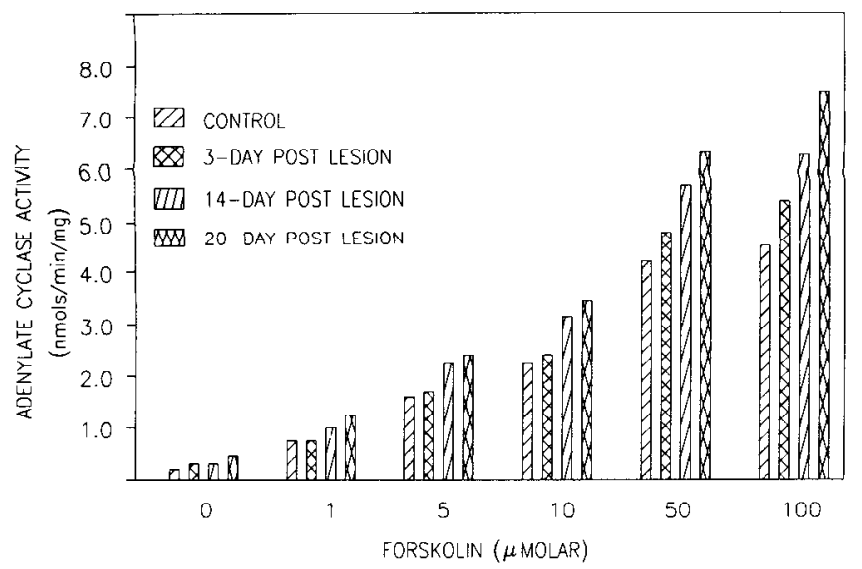

Figure 3. Forskolin-sensitive adenylate cyclase activity in control or lesioned membranes. Olfactory tubercle membranes from control and lesioned animals were prepared as described. Adenylate cyclase activity, in the presence of increasing concentrations of forskolin, was assayed as described in Materials and Methods. lesioned rats (data not shown). Activity in the presence of GTP only was higher in 14 and $20 \mathrm{~d}$ lesioned animals compared to controls. When dopamine was added, the enzyme activity increase in membranes from lesioned animals was higher than in controls, and there was no change in the apparent $K_{\mathrm{a}}$ for dopamine.

The data in Figure 1 also suggest that forskolin-stimulated $\mathrm{C}$ activity in the olfactory tubercle increased following bulbectomy. To examine the question of whether lesioning changed the affinity of $\mathrm{C}$ for forskolin, we performed the experiment presented in Figure 3. Forskolin increased $\mathrm{C}$ activity in a dosedependent manner. Compared to controls, membranes from lesioned rats consistently displayed higher levels of $\mathrm{C}$ activity, while the apparent $K_{\mathrm{a}}$ remained unchanged in response to forskolin.

The increase in $\mathrm{C}$ activity observed in Figure 3 suggested that the levels of $\mathrm{C}$ within the membrane had increased. To examine this directly we used ${ }^{3} \mathrm{H}$-forskolin to label $\mathrm{C}$ (Table 1). Olfactory tubercle membranes from lesioned animals (at 14 and $20 \mathrm{~d}$ ) bound more ${ }^{3} \mathrm{H}$-forskolin than control membranes. Addition of a nonhydrolyzable guanine nucleotide analog, $\mathrm{Gpp}(\mathrm{NH}) \mathrm{p}$, to the assay increased the number of ${ }^{3} \mathrm{H}$-forskolin binding sites in membranes from 14 and $20 \mathrm{~d}$ lesioned animals. There was a difference in the level of ${ }^{3} \mathrm{H}$-forskolin binding in the presence of $\mathrm{Gpp}(\mathrm{NH}) \mathrm{p}$ in membranes from $20 \mathrm{~d}$, but not $14 \mathrm{~d}$, lesioned animals. The reasons for this are not readily apparent, but the difference may reflect differences in the rates of association of $\mathrm{N}_{\mathrm{s}}$ with $\mathrm{C}$ between 14 and $20 \mathrm{~d}$ lesioned membranes. $\mathrm{Gpp}(\mathrm{NH}) \mathrm{p}$ in the presence of magnesium activates $\mathrm{N}_{\mathrm{s}}$ (Sternweis et al., 1981) and promotes the formation of an activated complex consisting of $\mathrm{N}_{\mathrm{s}}$ and C. Seamon and Daly (1985) have previously suggested that the high-affinity forskolin binding sites are associated with this activated complex and may represent a ternary complex of $\mathrm{C}, \mathrm{N}_{\mathrm{s}}$, and forskolin. The data obtained in this study are in line with this view and suggest that lesion-induced sprouting triggers an increase in the level of $\mathrm{N}_{\mathrm{s}}$ and $\mathrm{C}$ in the postsynaptic membrane.

The results presented in Figure 1 indicate that $N_{s}$ activity in the olfactory tubercle (as measured with $\mathrm{NaF}$ ) increased following bulbectomy. This phenomenon was further examined by reconstituting solubilized $\mathrm{N}_{\mathrm{s}}$ (Table 2) with $\mathrm{cyc}^{-}$, a variant of the murine $\mathbf{S} 49$ lymphoma cell line that does not contain any functional $\mathrm{N}_{\mathrm{s}}$ activity (Ross and Gilman, 1980, for review). The results demonstrate that the GTP-and NaF-stimulated enzyme 
Table 1. Binding of ${ }^{3} \mathrm{H}$-forskolin to olfactory tubercle membranes after olfactory bulbectomy

\begin{tabular}{llll}
$\begin{array}{l}\text { Lesion } \\
\text { duration } \\
(\mathrm{d})\end{array}$ & Group & $\begin{array}{l}\text { 采 } \mathrm{H} \text {-forskolin bound } \\
\text { (fmol/mg protein) }\end{array}$ \\
\hline 14 & Control & $12 \pm 1.0(6)$ & $36 \pm 2.0(6)$ \\
& Lesion & $15 \pm 0.7(6)^{a}$ & $35 \pm 1.0(6)$ \\
20 & Control & $30 \pm 0.3(3)$ & $65 \pm 3.0(3)$ \\
& Lesion & $37 \pm 4.0(3)$ & $76 \pm 4.0(3)^{a}$
\end{tabular}

Olfactory tubercle membranes were prepared as described in Materials and Methods. ${ }^{3} \mathrm{H}$-forskolin binding to membranes was performed as described by Nelson and Seamon (1985). Gpp(NH)p (5'-guanylylimidodiphosphate), when present, was used at $100 \mu \mathrm{M}$. Values are means \pm SEM of the number of determinations shown in parentheses.

${ }^{a}$ Significantly different from the appropriate control $(p<0.05)$ using Student's $t$ test.

activity was higher in membrane extracts obtained from $20 \mathrm{~d}$ lesioned animals compared to controls. The increases in GTPand $\mathrm{NaF}$-stimulated enzyme activity were 34 and $24 \%$, respectively.

The results to this point indicate that olfactory bulbectomy elicits an increase in adenylate cyclase activity in the olfactory tubercles that is apparent $14 \mathrm{~d}$ after lesioning. Earlier reports have shown that tyrosine hydroxylase activity begins to increase around $7 \mathrm{~d}$, reaching a maximum $21 \mathrm{~d}$ after lesioning (Gilad and Reis, 1979). In a separate set of experiments we examined the question of whether changes in adenylate cyclase activity correlate with the initial increase in tyrosine hydroxylase activity, namely, at $7 \mathrm{~d}$ postlesioning (Table 3 ). The overall enzyme activity in these membranes was lower than that obtained in our earlier studies. The reason for this is not clear, but intrinsic differences in animals used in these and earlier experiments may be involved. There were no differences in basal or GTP-stimulated enzyme activity between control or lesioned groups. However, in lesioned rats there was an increase in dopamine-, $\mathrm{NaF}$-, and forskolin-stimulated enzyme activity, which amounted to 25,27 , and $36 \%$, respectively.

\section{Effect of olfactory bulbectomy on dopamine-receptor binding in the olfactory tubercle}

It was of interest to determine whether the consistent increase in dopamine-sensitive adenylate cyclase activity in deafferented olfactory tubercles correlated with altered binding density and/ or affinity of the dopamine receptors. It is generally accepted that there are 2 subclasses of dopamine receptors, namely, $D_{1}$ and $D_{2} . D_{1}$ receptors stimulate, whereas $D_{2}$ receptors inhibit adenylate cyclase via stimulatory $\left(\mathrm{N}_{\mathrm{s}}\right)$ and inhibitory $\left(\mathrm{N}_{\mathrm{i}}\right)$ guanine nucleotide regulatory proteins, respectively. The ligand ${ }^{3} \mathrm{H}$ spiperone was used here to specifically label $\mathrm{D}_{2}$ receptors (Leff et al., 1985) in control and deafferented membranes as shown in Figure 4. The inset shows the level of specific binding of the 2 groups as a function of increasing ${ }^{3} \mathrm{H}$-spiperone concentrations. The level of binding is saturable, and denervated membranes bind more ${ }^{3} \mathrm{H}$-spiperone than controls. Figure $4 \mathrm{dem}$ onstrates that after transforming the data according to Scatchard (1949), there is a single population of binding sites in both control and lesioned groups. The apparent dissociation constants $\left(K_{\mathrm{d}}\right)$ for control (137 pM) and lesioned (118 pM) groups are very similar; however, there are more receptor sites $\left(B_{\max }\right)$ in deafferented tissue (11.1 pM) compared to controls $(8.9 \mathrm{pM})$.

It is well known that $D_{1}$ receptors are positively coupled to adenylate cyclase (see Seeman, 1980, for review). To examine whether the density of $D_{1}$ receptors increased after lesioning, we used ${ }^{3} \mathrm{H}$-cis-flupenthixol to label these receptors (Leff et al.,
Table 2. Reconstitution of solubilized $\mathrm{N}_{\mathrm{s}}$ from olfactory tubercle membranes of control or $20 \mathrm{~d}$ lesioned rats

\begin{tabular}{lll} 
& \multicolumn{2}{l}{$\begin{array}{l}\text { Adenylate cyclase activity } \\
\text { (nmol/min/mg extract) }\end{array}$} \\
\cline { 2 - 3 } Group & GTP & $\mathrm{NaF}$ \\
\hline Control extract & $0.23 \pm 0.03$ & $6.52 \pm 0.02$ \\
Lesioned extract & $0.31 \pm 0.03^{a}$ & $8.13 \pm 0.19^{a}$
\end{tabular}

Olfactory tubercle membranes from control or $20 \mathrm{~d}$ lesioned rats were extracted with $1 \%$ cholate in $20 \mathrm{~mm}$ Tris $\mathrm{HCl}, \mathrm{pH} 8.0,1 \mathrm{~mm}$ EDTA, and 1 mM DTT (details in Materials and Methods). The soluble extract was reconstituted with $\$ 49 \mathrm{cyc}^{-}$ membranes as described by Sternweis et al. (1981). The increases in GTP- and NaF-stimulated enzyme activity were 34 and $24 \%$, respectively.

${ }^{a}$ Significantly different from the appropriate control $(p<0.05)$ using Student's $t$ test.

1985) as shown in Table 4. Olfactory tubercle membranes from lesioned animals bound more ${ }^{3} \mathrm{H}$-cis-flupenthixol than membranes from control animals. The increase in the density of $D_{1}$ receptors was $46 \%$. These increases in receptor density of both $\mathrm{D}_{1}(46 \%$, Table 4$)$ and $\mathrm{D}_{2}(25 \%$, Fig. 4) at $20 \mathrm{~d}$ after lesioning correlate with the increase in dopamine-sensitive adenylate cyclase activity (25\%, Fig. 1$)$.

\section{Discussion}

Removal of the olfactory bulbs triggers sprouting of intact dopaminergic axons in the partially deafferented olfactory tubercles (Gilad and Reis, 1979; Moore, 1974). The dopaminergic sprouting has been identified by an increase in the amount and activity of tyrosine hydroxylase, by an increased uptake of ${ }^{3} \mathrm{H}$ dopamine into synaptosomes, and by the increased immunoreactive staining of tyrosine hydroxylase-containing axon terminals (Gilad and Reis, 1979). These arc lesion-induced neuroplastic events involving presynaptic parameters associated with dopaminergic innervation. The aim of this study was to examine whether postsynaptic dopamine-related constituents such as adenylate cyclase and receptor density are concurrently altered in the deafferented olfactory tubercles.

This work demonstrates an increase in dopamine-sensitive adenylate cyclase activity 7,14 , and $20 \mathrm{~d}$ postlesion. This change could be due, at least in part, to an increased number of dopamine receptors and/or an increased affinity of existing receptors for dopamine. The results of this study indicate that there were increases of 46 and $25 \%$ in the density of $D_{1}$ and $D_{2}$ receptors, respectively, in membranes from $20 \mathrm{~d}$ lesioned animals. It has recently been reported that activation of $D_{2}$ receptors by dopamine results in inhibition of adenylate cyclase activity in the anterior pituitary (Borgundvaag and George, 1985) and rat striatum (Onali et al., 1985). It is possible that the changes in adenylate cyclase activity observed in this study in

Table 3. Adenylate cyclase activity in olfactory tubercule membranes from control or $7 \mathrm{~d}$ lesioned rats

Adenylate cyclase activity ( $\mathrm{pmol} / \mathrm{min} / \mathrm{mg}$ protein)

\begin{tabular}{llllll}
\cline { 2 - 6 } Group & Basal & GTP & GTP/DA & NaF & Forskolin \\
\hline Control & $82 \pm 3$ & $123 \pm 22$ & $153 \pm 2$ & $226 \pm 27$ & $1569 \pm 218$ \\
Lesion & $79 \pm 3$ & $131 \pm 7$ & $185 \pm 4^{a}$ & $288 \pm 24^{a}$ & $1916 \pm 98^{a}$
\end{tabular}

Rats were sham-operated or lesioned as described in Materials and Methods. Animals were sacrificed; and olfactory tubercles were removed and processed for assay of adenylate cyclase activity as described.

The concentrations of GTP, dopamine (DA), NaF, and forskolin were $100 \mu \mathrm{M}$, $100 \mu \mathrm{M}, 10 \mathrm{~mm}$, and $100 \mu \mathrm{M}$, respectively. The $\mathrm{NaF}$ solution contained $20 \mu \mathrm{M}$ $\mathrm{AlCl}_{3}$. Values are means \pm SD of 4 determinations.

a Significantly different from control $(p<0.05)$ using Student's $t$ test. 
Figure 4. ${ }^{3} \mathrm{H}$-spiperone binding to $\mathrm{D}_{2}$ receptors in control or lesioned animals. ${ }^{3} \mathrm{H}$-spiperone binding to olfactory tubercle membranes from control or lesioned animals was assayed as described. Non-specific binding was determined in the presence of $1 \mu \mathrm{M}$ $( \pm)$-butaclamol. Transformation of the data was according to the procedure of Scatchard (1949).

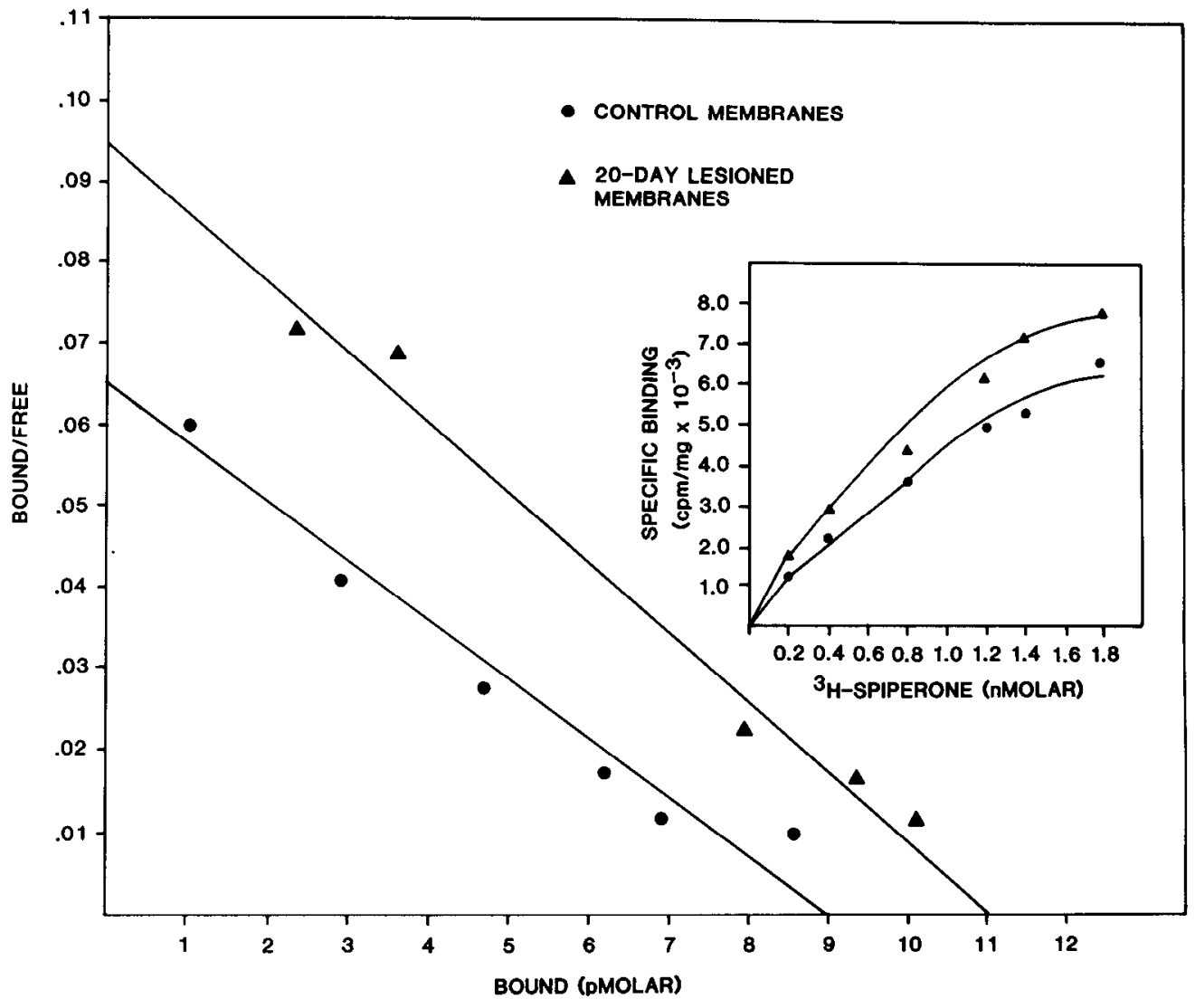

response to dopamine may result from the algebraic sum of $D_{1}$ stimulation and $\mathrm{D}_{2}$ inhibition.

$\mathrm{NaF}$ and forskolin activate adenylate cyclase by interacting with $\mathrm{N}_{\mathrm{s}}$ and $\mathrm{C}$, respectively. $\mathrm{N}_{\mathrm{s}}$-which consists of 3 subunits with apparent molecular weights of $45,000(\alpha), 35,000(\beta)$, and $10,000(\gamma)$ (Bokoch et al., 1984; Hildebrandt et al., 1984)hydrolyzes GTP to GDP as part of its regulatory cycle (Brandt et al., 1983; Cassel and Selinger, 1979) and is ADP-ribosylated by cholera toxin (Ross and Gilman, 1980, for review). Available evidence suggests that receptor-mediated stimulation of adenylate cyclase activity occurs when the subunits of $\mathrm{N}_{\mathrm{s}}$ dissociate (Northup et al., 1982, 1983a, b) and that $\mathrm{N}_{\mathrm{s} \alpha}$ is the subunit that interacts with $C$ (Smigel et al., 1984). The results of this study indicate that the $\mathrm{NaF}$ - and forskolin-stimulated enzyme activity is greater in olfactory tubercle membranes from lesioned animals. These data suggest that bulbectomy elicits either (1) higher levels of $\mathrm{N}_{\mathrm{s}},(2)$ increased rates of dissociation and, therefore,

Table 4. Binding of ${ }^{3} \mathrm{H}$-cis-flupenthixol to olfactory tubercle membranes of control or $20 \mathrm{~d}$ lesioned rats

\begin{tabular}{lll} 
Group & $\begin{array}{l}{ }^{3} \mathrm{H}-\text { cis-flupen- } \\
\text { thixol bound } \\
\text { (fmol/mg protein) }\end{array}$ & $\%$ Control \\
\hline Control & 327 & 100 \\
Lesion & 479 & 146
\end{tabular}

Rats were sham-operated or lesioned and allowed to recover for $20 \mathrm{~d}$ and then sacrificed. Olfactory tubercles were removed and membranes prepared as described in Materials and Methods. ${ }^{3} \mathrm{H}$-cis-flupenthixol binding to membranes was performed as described by Leff et al. (1985). Total binding was measured in the presence of $30 \mathrm{~nm}$ spiperone, which blocks the binding of ${ }^{3} \mathrm{H}$-cis-flupenthixol to $\mathrm{D}_{2}$ receptors (Leff et al., 1985), while nonspecific binding was measured in the presence of 1 $\mu \mathrm{M}(+)$-butaclamol plus $30 \mathrm{~nm}$ spiperone. The values are the means of 2 separate experiments done in triplicate. activity of $\mathrm{N}_{s}$, or (3) increased levels and/or activity of $\mathrm{C}$. We have attempted to examine the second possibility by reconstituting solubilized $\mathrm{N}_{\mathrm{s}}$ from control or lesioned membranes with cyc $^{-}$S49 lymphoma membranes. The results demonstrate that the intrinsic activity of $\mathrm{N}_{\mathrm{s}}$ was greater in olfactory tubercles from lesioned animals; however, it is not known whether the dissociation of $\mathrm{N}_{\mathrm{s}}$ was increased as well.

The findings of this study suggest that bulbectomy results in increased levels and activity of the catalytic subunit of adenylate cyclase $(\mathrm{C})$. The increase in forskolin-stimulated enzyme activity observed at $3 \mathrm{~d}$ after lesioning may be due to an increase in the turnover of $\mathrm{C}$. The changes in forskolin-sensitive activity, as well as in forskolin-binding, 14 and $20 \mathrm{~d}$ after lesioning reflect an increase in the levels and turnover of $C$.

The changes in adenylate cyclase activity observed in this study are similar to those in tyrosine hydroxylase activity obtained following bulbectomy. That is, the $25 \%$ increase in dopamine-sensitive adenylate cyclase activity observed in this study corresponds with the increase in tyrosine hydroxylase activity (25\%) after 3 weeks of olfactory bulbectomy (Gilad and Reis, 1979). The increase in tyrosine hydroxylase activity represents a presynaptic event, while the increase in adenylate cyclase activity may reflect changes in enzyme activity occurring both preand postsynaptically. However, this is unlikely, since Church et al. (1982) demonstrated that most of the adenylate cyclase in the olfactory tubercle is located postsynaptic to the dopaminergic projections.

The increase in adenylate cyclase activity is unlikely to be due to a loss of cellular elements. In fact, evidence suggests that the number of glial cells, especially astrocytes, increases in response to injury, leading to the development of the "glial scar" (see Nathaniel and Nathaniel, 1981, for review). In addition, we have observed that the protein contents of olfactory tubercles from sham-operated or lesioned animals were the same (unpublished observations). Therefore, the increase in adenylate 
cyclase activity observed in this study in response to lesioning represents changes in levels of the enzyme in a neuronal compartment and not changes in the levels of non-neuronal cells or tissue protein content.

While it is difficult to ascertain the precise molecular events that occur within the deafferented olfactory tubercle and their sequence, the available evidence indicates that changes occur in both the pre- and postsynaptic neurons. In the presynaptic neuron, one of the first molecular events apparently occurs in the sprouting dopaminergic perikaryon (Gilad and Reis, 1979). The newly synthesized molecules (structural proteins and the biosynthetic enzyme tyrosine hydroxylase) are transported along the axon towards the terminals. Sprouting becomes apparent as carly as $7 \mathrm{~d}$ after lesioning (Gilad and Reis, 1979); this finding corresponds with the observed increase in adenylate cyclase in this study, which occurs at neurons postsynaptic to the projecting dopaminergic axons (Church et al., 1982). It has been reported that the structure, chemistry, and physiology of the postsynaptic membrane can be altered by synaptic activity (Cotman et al., 1981, for review). Thus, Steward and Levy (1982) and Steward (1983a) have demonstrated that, in many CNS neurons, polyribosomes accumulate at the base of dendritic spines, the postsynaptic structures on which axon terminals impinge. Furthermore, the number of polyribosomes and the incorporation of precursor proteins were increased during the lesion-induced sprouting in the dentate gyrus, peaking at 6-8 d after lesioning (Steward, 1983b). This correlated well with the initial period of axonal sprouting and reactive synaptogenesis (Fass and Steward, 1983).

Although the available evidence suggests that denervation elicits responses in both the pre- and postsynaptic neurons, the sequence of events leading to the establishment of new synaptic connections remains to be elucidated. It is tempting to speculate that denervation of the olfactory tubercle triggers an increase in polyribosomal activity that promotes the de novo synthesis of both $D_{1}$ and $D_{2}$ receptors, as well as of the adenylate cyclase components $\mathrm{N}_{\mathrm{s}}$ and $\mathrm{C}$ in the postsynaptic membrane. At present it is not known if the newly synthesized postsynaptic receptors attract the sprouting presynaptic dopaminergic axons to the denervated site. Alternatively, the postsynaptic neurons may release trophic factors that direct the sprouting fibers to the newly synthesized receptors. Recently, Loy et al. (1983) demonstrated that lesioning of the cholinergic input to the hippocampus elicits sprouting of sympathetic fibers to the denervated area. This sprouting was associated with the development of $\alpha_{1}$-adrenergic receptors in the denervated area, which preceded the appearance and maximal development of the sprouting fibers. The relationship between the development of lesion-induced receptors and axonal sprouting is still subject to speculation (Pestronk and and Drachman, 1978; Tayrien and Loy, 1984); however, we feel that the tools of molecular biology and classical biochemistry, if brought to bear on this problem, may be useful in providing a solution to the question of neuronal development and plasticity.

\section{References}

Bokoch, G. M., T. Katada, J. K. Northup, M. Ui, and A. G. Gilman (1984) Purification and properties of the inhibitory guanine-nucleotide-binding regulatory component of adenylate cyclase. J. Biol. Chem. 259: 3560-3567.

Borgundvaag, B., and S. M. George (1985) Dopamine inhibition of anterior pituitary adenylate cyclase is mediated through the highaffinity state of the $D_{2}$ receptor. Life Sci. 37: 370-386.

Bradford, M. M. (1976) A rapid and sensitive method for quantitation of microgram quantities of protein utilizing the principle of dyebinding. Anal. Biochem. 72: 248-254.

Brandt, D. R., T. Asano, S. E. Pederson, and E. M. Ross (1983) Reconstitution of catecholamine-stimulated guanosine-triphosphatase activity. Biochemistry 22: 4357-4362.
Cassel, D., and Z. Selinger (1979) Mechanism of adenylate cyclase activation through the beta-adrenergic receptor. Catecholamine-induced displacement of bound GDP by GTP. Proc. Natl. Acad. Sci. USA 75: 4155-4159.

Church, A. C., B. S. Bunney, and N. R. Krieger (1982) Neuronal localization of dopamine-sensitive adenylate cyclase within the rat olfactory tubercle. Brain Res. 234: 369-376.

Cotman, C. W., ed. (1978) Neuronal Plasticity, Raven, New York.

Cotman, C. W., M. Nieto-Sampedro, and E. W. Harris (1981) Synapse replacement in the nervous system of adult vertebrates. Physiol. Rev. 61: 684-784.

Drummond, G. I. (1983) Cyclic nucleotides in the central nervous system. Adv. Cyclic Nucleotide Res. 15: 373-494.

Fass, B., and O. Steward (1983) Increases in protein precursors incorporation in the denervated neuropil of the dentate gyrus during reinnervation. Neuroscience 9: 653-664.

Gilad, G. M., and D. J. Reis (1979) Collateral sprouting in central mesolimbic dopamine neurons: Biochemical and immunocytochemical evidence of changes in the activity and distribution of tyrosine hydroxylase in terminal fields and in cell bodies of A10 neurons. Brain Res. 160: 17-36.

Green, D. A., and R. B. Clark (1982) Direct evidence for the role of the coupling proteins in forskolin activation of adenylate cyclase. $J$. Cyclic Nucleotide Res. 8: 337-346.

Hildebrandt, J. D., J. Codina, R. Risinger, and L. Birnbaumer (1984) Identification of a $\gamma$-subunit associated with the adenylyl cyclase regulatory proteins $\mathrm{N}_{\mathrm{s}}$ and $\mathrm{N}_{\mathrm{i}}$. J. Biol. Chem. 259: 2039-2042.

Krieger, N. R. (1980) Localization of dopamine-sensitive adenylate cyclase within the rat olfactory tubercle. Brain Res. 183: 383-391

Leff, S. E., M. W. Hamblin, and J. Creese (1985) Interactions of dopamine agonists with brain $D_{1}$ receptors labeled by ${ }^{3} \mathrm{H}$-antagonists. Mol. Pharmacol. 27: 171-183.

Loy, R., A. L. Morrow, and I. Creese (1983) Cholinergic denervation induces adrenergic receptor increases: Correlation with sympathetic axon sprouting in hippocampus. In Nervous System Regeneration, B. Haber et al., eds., pp. 409-415, Liss, New York.

Moore, R. Y. (1974) Central regeneration and recovery of function: The problem of collateral reinnervation. In Plasticity and Recovery of Function in the Central Nervous System, D. G. Stein, J. J. Rosen, and N. Butters, eds., pp. 111-128, Academic, New York.

Nathaniel, E. J. H., and D. R. Nathaniel (1981) The reactive astrocyte. Adv. Cell. Neurobiol. 2: 249-301.

Nelson, C. A., and K. B. Seamon (1985) Regulation of ${ }^{3} \mathrm{H}$-forskolin binding to human platelet membranes by GppNHp, NaF and prostaglandin E. FEBS Lett. 183: 349-352.

Northup, J. K., M. D. Smigel, and A. G. Gilman (1982) The guanine nucleotide activating site of the regulatory component of adenylate cyclase. J. Biol. Chem. 257: 11416-11423.

Northup, J. K., M. D. Smigcl, P. C. Sternweis, and A. G. Gilman (1983a) The subunits of the stimulatory regulatory component of adenylate cyclase. J. Biol. Chem. 258: 11369-11376.

Northup, J. K., P. C. Sternweis, and A. G. Gilman (1983b) The subunits of the stimulatory regulatory component of adenylate cyclase. J. Biol. Chem. 258: 11361-11368.

Onali, P., M. C. Olianas, and G. L. Gessa (1985) Characterization of dopamine receptors mediating inhibition of adenylate cyclase activity in rat striatum. Mol. Pharmacol. 28: 138-145.

Pestronk, A., and D. B. Drachman (1978) Motor nerve sprouting and acetylcholine receptors. Science 199: 1223-1225.

Ross, E. M., and A. G. Gilman (1980) Biochemical properties of hormone-sensitive adenylate cyclase. Annu. Rev. Biochem. 49: 533564.

Ross, E. M., A. C. Howlett, K. M. Ferguson, and A. G. Gilman (1978) Reconstitution of hormone-sensitive adenylate cyclase activity with resolved components of the enzyme. J. Biol. Chem. 253: 6401-6412.

Salomon, Y. (1979) Adenylate cyclase assay. Adv. Cyclic Nucleotide Res. 10: 35-56.

Scatchard, G. (1949) The attractions of proteins for small molecules and ions. Ann. NY Acad. Sci. 51: 660-672.

Schaffner, W., and C. Weissman (1973) A rapid, sensitive and specific method for the determination of protein in dilute solution. Anal. Biochem. 56: 502-514.

Seamon, K. G., and J. W. Daly (1981) Activation of adenylate cyclase by the diterpene forskolin does not require the guanine nucleotide regulatory protein. J. Biol. Chem. 256: 9799-9801.

Seamon, K. G., and J. W. Daly (1985) High-affinity binding of for- 
skolin to rat brain membranes. Adv. Cyclic Nucleotide Res. 19: 125135.

Seeman, P. (1980) Brain dopamine receptors. Pharmacol. Rev. 32 . 229-313.

Smigel, M. D., T. Katada, J. K. Northup, G. M. Bokoch, M. Ui, and A. G. Gilman (1984) Mechanisms of guanine nucleotide-mediated regulation of adenylate cyclase activity. Adv. Cyclic Nucleotide Res. 17: 1-18.

Sternweis, P. C., and A. G. Gilman (1982) Aluminum: A requirement for the activation of the regulatory component of adenylate cyclase by fluoride. Proc. Natl. Acad. Sci. USA 79: 4888-4891.

Sternweis, P. C., J. K. Northup, M. D. Smigel, and A. G. Gilman (1981) The regulatory component of adenylate cyclase. J. Biol. Chem. 256: $11517-11526$.

Steward, O. (1983a) Polyribosomes at the base of dendritic spines of central nervous system neurons: Their possible role in synapse construction and modification. Cold Spring Harbor Symp. Quant. Biol. 48: 745-759.

Steward, O. (1983b) Alterations in polyribosomes associated with dendritic spines during the reinnervation of the dentate gyrus of the adult rat. J. Neurosci. 3: 177-188.

Steward, O., and W. B. Levy (1982) Preferential localization of polyribosomes under the base of dentritic spines in the granule cells of the dentate gyrus. J. Neurosci. 2: 284-291.

Tayrien, M. W., and R. Loy (1984) Computer-assisted image analysis to quantify regional and specific receptor ligand binding: Upregulation of $\left[{ }^{3} \mathrm{H}\right] \mathrm{QNB}$ and $\left[{ }^{3} \mathrm{H}\right] \mathrm{WB} 4101$ binding in denervated hippocampus. Brain Res. Bull. 13: 743-750.

Ungerstedt, U. (1971) Stereotaxic mapping of the monamine pathways in the rat brain. Acta Physiol. Scand. [Suppl.]367: 1-48. 